\title{
SIFAT PAPAN BLOK SENGON DENGAN VENIR SILANG KAYU TUSAM
}

\section{(The Properties of Sengon Blockboard with Cross Core Layer from Tusam Wood)}

\author{
Oleh/By :
}

\author{
M.I. Iskandar \& I.M. Sulastiningsih ${ }^{1)}$
}

\begin{abstract}
Experimental blockboards (5-ply) were made of sengon wood (Paraserianthes falcataria) and tusam wood (Pinus merkusii) glued with urea formaldebyde. The core and outer layers made of sengon wood while the cross core layer made of tusam wood. Thickness of veneers were $2 \mathrm{~mm}$ for face and back layers (outer layer) and $3 \mathrm{~mm}$ for cross core layer. The dimension of strip (core layer) divided into two different thickness $(1 \mathrm{~cm}$ and $1,5 \mathrm{~cm})$ and three different width $(0.7$ $\mathrm{cm} ; 2.5 \mathrm{~cm}$ and $7.6 \mathrm{~cm}$ ). The blokboard properties were tested according to the Indonesian Standard (SNI) included moisture content, density, bonding strength and delamination. The bending strength of blockboard was tested according to the Germany Standard (DIN) while the dimension expansion of blockboard was tested according to the American Standard (ASTM). The objective of this study was to determine the effect of the strip dimension on the properties of sengon blockboard with cross core layer from tusam wood.

The results revealed that the average moisture content of blockboard was $12 \%$ while the average density of blockboard was $0.42 \mathrm{~g} / \mathrm{cm} 3$. The width of strip affected the thickness swelling and width expansion of blockboard. Thickness of strip affected the width expansion of blockboard however did not affected the thickness sweliing and length expansion of blockboard. The moisture resistant bonding strength of blockboard based on tensile shear strength and delamination tests met the SNI requirement. The bending strength of sengon blockboard increased by $6.2 \%$ (parallel to grain) and 18.6\% (perpendicular to grain) respectively when using tusam wood as the cross core layer of sengon blockboard. The bending strength parallel to grain of sengon blockboard with cross core layer of tusam wood met the DIN standard requirement.
\end{abstract}

Keywords: Sengon, tusam, cross core layer, blockboard

\begin{abstract}
ABSTRAK
Papan blok (5 lapis) sekala laboratorium dibuat dari kayu sengon (Paraserianthes falcataria) dan kayu tusan (Pinus merkusii) yang direkat dengan perekat urea formaldehida. Venir luar dan bilah inti papan blok terbuat dari kayu sengon sedangkan venir silang terbuat dari kayu tusam. Tebal venir luar $2 \mathrm{~mm}$ sedangkan tebal venir silang $3 \mathrm{~mm}$. Ukuran bilah inti terdiri dari dua macam ketebalan (1 dan 1,5 cm)
\end{abstract}

${ }^{1)}$ Peneliti pada Pusat Penelitian dan Pengembangan Hasil Hutan, Bogor 
dan 3 macam lebar (0,7, 2,5 dan 7,6 cm). Sifat papan blok diuji menurut Standar Indonesia (SNI) meliputi kadar air, kerapatan, keteguhan rekat dan delaminasi. Pengujian keteguhan lentur papan blok dilakukan menurut Standar Jerman (DIN) sedangkan pengujian pengembangan dimensi papan blok dilakukan menurut Standar Amerika (ASTM). Tujuan penelitian ini adalah untuk mengetahui pengaruh ukuran bilah inti terhadap sifat papan blok sengon dengan venir silang kayu tusam.

Hasil penelitian menunjukkan bahwa kadar air rata-rata papan blok adalah 12\% sedangkan kerapatan rata-rata papan blok adalah $0,42 \mathrm{~g} / \mathrm{cm}^{3}$. Lebar bilah inti berpengaruh terhadap pengembangan tebal dan pengembangan lebar papan blok. Tebal bilah inti berpengaruh terhadap pengembangan lebar papan blok tetapi tidak berpengaruh terhadap pengembangan tebal dan pengembangan panjang papan blok. Keteguhan rekat papan blok yang diuji berdasarkan uji geser tarik dan uji delaminasi memenuhi persyaratan Standar Indonesia (SNI). Penggunaan venir silang kayu tusam dalam pembuatan papan blok sengon meningkatkan keteguhan lentur sebesar 6,2\% pada arah sejajar serat dan 18,6\% pada arah tegak lurus serat. Keteguhan lentur sejajar serat papan blok sengon yang dibuat dengan menggunakan venir silang kayu tusam semuanya memenuhi persyaratan Standar Jerman (DIN).

Kata kunci : Sengon, tusam, venir silang, papan blok

\section{PENDAHULUAN}

Pohon sengon (Paraserianthes falcataria) termasuk jenis pohon yang banyak ditanam oleh rakyat di Jawa. Selain itu Perum Perhutani telah mengembangkan tanaman sengon di beberapa kabupaten di Jawa Barat dengan total luas sebesar 87.094 ha (Anonim, 2004). Jenis tanaman sengon termasuk cepat tumbuh. Pada umur 6 tahun pohon sengon dapat menghasilkan kayu bundar sebanyak $156 \mathrm{~m}^{3}$ per hektar dan pada umur 15 tahun dapat menghasilkan kayu bundar $372 \mathrm{~m}^{3}$ per hektar (Prajadinata dan Masano, 1989).

Pohon sengon dapat mencapai diameter $80 \mathrm{~cm}$, tinggi $40 \mathrm{~m}$ dan tinggi bebas cabang 10 - $30 \mathrm{~m}$. Kayunya mempunyai berat jenis $0,33(0,24$ - 0,49) termasuk kelas kuat IV - V, kelas awet IV - V dan ketahanannya terhadap rayap kayu kering termasuk kelas III (Martawijaya, Kartasujana, Mandang, Prawira dan Kadir, 1989). Seiring dengan kemajuan teknologi dan perkembangan industri pengolahan kayu di Indonesia dewasa ini kayu sengon banyak digunakan sebagai bahan baku industri pengerjaan kayu, seperti papan sambung (jointed board) dan hasilnya diekspor ke Jepang. Dengan berkembangnya industri papan sambung tersebut maka akan diperoleh limbah berupa sebetan dan potongan ujung. Bahan ini masih dapat dimanfaatkan sebagai inti papan blok sehingga dapat meningkatkan efisiensi pemakaian kayu sengon tersebut.

Pohon tusam (Pinus merkusii) termasuk jenis pohon yang banyak ditanam oleh Perum Perhutani di Jawa yaitu seluas 745.456 ha (Anonim, 1995) yang berarti sekitar setengah luas hutan jati (1.331.282 ha). Daerah penyebaran pohon tusam adalah Aceh, Sumatera Utara, Sumatera Barat dan seluruh Jawa. Tinggi pohon 20 - $40 \mathrm{~m}$ dengan panjang batang bebas cabang 2 - $23 \mathrm{~m}$, diameter sampai $100 \mathrm{~cm}$, tidak berbanir. Kayu tusam mempunyai berat jenis 0,55 (0,40 - 0,75), termasuk kelas kuat III dan kelas awet IV. Daya tahannya terhadap rayap kayu kering termasuk kelas V. Tusam dilaporkan sebagai jenis kayu yang mudah dipotong dan dibelah, tetapi sukar digergaji dan diserut, mungkin karena banyak mengandung damar. 
Sementara itu pengujian menunjukkan bahwa kayu tusam mempunyai sifat pemesinan yang bervariasi dari buruk sampai baik, yaitu kayunya dapat diserut, dibentuk, dibuat lubang, persegi yang diamplas dengan hasil baik, dapat dibubut dengan hasil sedang, tetapi pemboran memberi hasil buruk. Kayu tusam dapat dipergunakan untuk bangunan perumahan, lantai, mebel, kotak dan tangkai korek api, potlot (dengan pengolahan khusus), pulp, tiang listrik (diawetkan), papan wol kayu dan kayu lapis (Martawijaya et al., 1989).

Papan blok adalah kayu lapis yang intinya berupa bilah kayu gergajian. Kegunaan papan blok yang terutama adalah untuk bahan mebel sebagai pengganti multipleks. Di Indonesia papan blok mulai dibuat pada tahun 1972 oleh perusahaan kabinet mesin jahit dan mulai tahun 1978 dibuat oleh pabrik kayu lapis. Pada saat ini di Indonesia terdapat 59 pabrik papan blok yang sebagian besar terpadu dengan pabrik kayu lapis (Sutigno, 1991).

Berdasarkan lebar bilah inti, dikenal 3 macam papan blok yaitu " batten board" dengan lebar bilah inti sampai dengan $76 \mathrm{~mm}$, "block board" dengan lebar belah inti sampai dengan $25 \mathrm{~mm}$ dan " lamin board" dengan lebar bilah inti sampai dengan $7 \mathrm{~mm}$ (Anonim, 1966). Kualitas papan blok tergantung dari ukuran bilah yang direkat atau disusun sebagai lapisan inti papn blok. Lebar bilah inti papan blok akan berpengaruh terhadap kestabilan dimensi papan blok, banyaknya perekat yang diperlukan dan kekuatannya. Penelitian yang dilakukan oleh Sulastiningsih, Sutigno dan Iskandar (1995) menunjukkan bahwa keteguhan lentur papan blok yang memenuhi syarat Standar Jerman adalah yang intinya terbuat dari bilah lebar $0,7 \mathrm{~cm}$ dan tebal $1 \mathrm{~cm}$. Untuk meningkatkan kekuatan papan blok perlu diteliti penggunaan venir silang dari kayu tusam.

Hidayat, Tambunan dan Sutigno (1978) telah melakukan penelitian mengenai papan blok dengan berbagai jenis kayu dan tebal venir. Lapisan inti papan blok dibuat dari kayu balsa (Ochroma bicolor). Venir yang digunakan baik untuk venir luar maupun venir silang terdiri dari tiga jenis kayu yaitu balsa (Ochroma bicolor), meranti merah (Shorea leprosula) dan keruing (Dipterocarpus gracilis) masing-masing dengan ketebalan 1,5 dan $3 \mathrm{~mm}$. Hasil penelitian menunjukkan bahwa pemakaian venir silang dari kayu yang lebih kuat atau berat jenisnya tinggi akan meningkatkan keteguhan lentur papan blok.

\section{BAHAN DAN METODE}

\section{A. Bahan}

Kayu sengon (Paraserianthes falcataria) dan kayu tusam (Pinus merkusii) berasal dari Jawa Barat, berbentuk dolok dengan diameter rata-rata 37 dan $39 \mathrm{~cm}$ dan panjang 1,5 m. Perekat yang digunakan adalah urea formaldehida cair dengan pengeras $\mathrm{NH}_{4} \mathrm{Cl}$ dan ekstender terigu.

\section{B. Metode}

\section{Pembuatan venir}

Dolok kayu sengon dibuat venir dengan menggunakan mesin kupas dengan ketebalan 2 $\mathrm{mm}$, sedangkan kayu tusam dikupas dengan target ketebalan $3 \mathrm{~mm}$. Venir yang dihasilkan sebagian dipotong menjadi ukuran $40 \times 40 \mathrm{~cm}$ dan sisanya dipotong menjadi ukuran $100 \times 20$ $\mathrm{cm}$ baik memanjang serat maupun tegak lurus serat. Venir tersebut kemudian dikeringkan hingga kadar airnya sekitar $10 \%$. 


\section{Pembuatan bilah}

Dolok kayu sengon dibelah menjadi papan dan diserut dengan ketebalan 1 dan 1,5 cm. Papan (untuk masing-masing ketebalan) dibelah menjadi bilah dengan 3 macam ukuran lebar yaitu 0,$7 ; 2,5$ dan 7,6 cm. Bilah dipotong dengan ukuran panjang yaitu 20, 40 dan $100 \mathrm{~cm}$, dan dikeringkan hingga kadar airnya sekitar $10 \%$.

\section{Pembuatan papan blok}

Papan blok yang dibuat adalah 5 lapis. Tebal venir luar $2 \mathrm{~mm}$ terbuat dari kayu sengon, tebal venir silang $3 \mathrm{~mm}$ terbuat dari kayu tusam. Inti papan blok terbuat dari kayu sengon dengan tebal bilah $1 \mathrm{~cm}$ dan 1,5 cm. Lebar bilah inti papan ada 3 macam yaitu 0,70;2,5 dan $7,6 \mathrm{~cm}$.

Untuk pengujian keteguhan rekat dan kestabilan dimensi maka ukuran papan blok yang dibuat untuk masing-masing ketebalan dan lebar bilah inti adalah 40 x $40 \mathrm{~cm}$ sesuai ukuran lempeng mesin kempa panas yaitu $40 \times 40 \mathrm{~cm}$, sedangkan ukuran contoh ujinya kurang dari $40 \mathrm{~cm}$. Untuk setiap ukuran lebar dan tebal bilah inti papan blok dibuat 4 buah papan. Perekat yang digunakan mempunyai komposisi urea formaldehida cair 100 gram, terigu 20 gram dan pengeras 0,5 gram. Berat labur perekat adalah 170 gram per meter persegi permukaan. Bahan papan blok dikempa dingin selam 10 menit kemudian dikempa panas pada suhu $110^{\circ} \mathrm{C}$ dengan tekanan $15 \mathrm{~kg} / \mathrm{cm}^{2}$ selama 6 menit.

Untuk pengujian keteguhan lentur (modulus patah) ukuran papan blok yang dibuat adalah 20 x $100 \mathrm{~cm}$ baik dengan arah venir luar sejajar serat atau tegak lurus serat. Papan blok dibuat dengan perekat urea formaldehida cair dengan komposisi dan berat labur perekat seperti tersebut diatas. Bahan papan blok dikempa dingin selama 24 jam. Pengempaan panas tidak dapat dilakukan karena lempeng mesin kempa panas berukuran 40 x $40 \mathrm{~cm}$, sedangkan panjang contoh uji keteguhan lentur $70 \mathrm{~cm}$. Untuk setiap ukuran lebar dan tebal bilah inti papan blok dibuat 4 buah papan baik untuk pengujian keteguhan lentur sejajar serat maupun tegak lurus serat.

\section{Pengujian papan blok}

Pembuatan contoh uji dilakukan paling cepat 7 hari setelah pembuatan papan blok. Sifat papan blok yang diuji meliputi kadar air, kerapatan, pengembangan dimensi (tebal, panjang, lebar), delaminasi, keteguhan rekat (beban putus dan kerusakan kayu), keteguhan lentur (modulus patah). Pengujian sifat papan blok dilakukan menurut Standar Indonesia (Anonim, 2002), meliputi kadar air, kerapatan dan delaminasi. Pengujian keteguhan rekat papan blok dilakukan dengan menggunakan Standar Indonesia kayu lapis penggunaan umum (Anonim, 2002). Pengujian pengembangan dimensi (tebal, panjang, lebar) dilakukan menurut Standar Amerika (Anonim, 1995b), sedangkan pengujian keteguhan lentur papan blok dilakukan menurut Standar Jerman (Anonim, 1975). Nilai hasil pengujian yang dibandingkan dengan standar adalah nilai rata-rata dari masing-masing sifat yang diuji.

\section{Rancangan percobaan}

Rancangan percobaan yang digunakan dalam penelitian ini adalah rancangan acak lengkap dengan percobaan faktorial $3 \times 2$. Faktor pertama adalah lebar bilah inti yang terdiri 
atas 3 taraf faktor yaitu a1 $(0,70 \mathrm{~cm})$, a2 $(2,5 \mathrm{~cm})$ dan a3 $(7,6 \mathrm{~cm})$. Faktor kedua adalah tebal bilah inti yang terdiri atas 2 taraf faktor yaitu b1 $(1 \mathrm{~cm})$ dan b2 $(1,5 \mathrm{~cm})$. Banyaknya ulangan adalah 4 buah.

\section{HASIL DAN PEMBAHASAN}

Nilai rata-rata sifat fisis papan blok tercantum pada Tabel 1 sedangkan nilai rata-rata sifat mekanis papan blok tercantum pada Tabel 2. Untuk mengetahui pengaruh ukuran bilah inti terhadap sifat papan blok dilakukan sidik ragam dan hasilnya tercantum pada Tabel 3 sedangkan hasil uji bedanya tercantum pada Lampiran 1.

Kadar air papan blok rata-rata 11,96\% dengan kisaran 11,77 - 12,06\%. Kadar air ini memenuhi persyaratan Standar Indonesia (Anonim, 2002) karena tidak lebih dari 14\%. Kerapatan rata-rata papan blok $0,42 \mathrm{~g} / \mathrm{cm}^{3}$ dengan kisaran $0,41-0,44 \mathrm{~g} / \mathrm{cm}^{3}$. Berat jenis ratarata kayu sengon 0,33 dengan kisaran 0,24 - 0,49 (Oey Djoen Seng, 1964). Sementara itu papan blok yang seluruhnya dibuat dari kayu sengon mempunyai kerapatan rata-rata 0,33 $\mathrm{g} / \mathrm{cm}^{3}$ dengan kisaran 0,30 - 0,36 g/ $\mathrm{cm}^{3}$ (Sulastiningsih et al., 1995). Dengan demikian kerapatan rata-rata papan blok yang diteliti lebih tinggi dari pada berat jenis rata-rata kayu sengon dan lebih tinggi dari pada kerapatan rata-rata papan blok sengon. Hal ini wajar karena pada penelitian ini digunakan venir silang tusam sedangkan bilah inti dan venir luarnya sengon. Berat jenis rata-rata kayu tusam $(0,55)$ lebih tinggi daripada berat jenis rata-rata kayu sengon (Oey Djoen Seng, 1964).

Pengembangan dimensi papan blok setelah direndam dalam air dingin selam 24 jam adalah 5,28\% (4,53 - 6,07\%) untuk pengembangan tebal, $0,49 \%(0,29-0,62 \%)$ untuk pengembangan panjang dan $0,59 \%(0,37-0,75 \%)$ untuk pengembangan lebar. Terlihat bahwa pengembangan tebal lebih besar dari pada pengembangan panjang dan lebar, sedangkan pengembangan panjang hampir sama dengan pengembangan lebar. Hal ini disebabkan oleh susunan papan blok yang bersilangan tegak lurus seperti kayu lapis. 
Tabel 1. Nilai rata-rata sifat fisis papan blok Tabel 1. Mean values of physical properties of block board

\begin{tabular}{|c|c|c|c|c|c|}
\hline \multirow[t]{2}{*}{ No } & \multirow{2}{*}{$\begin{array}{c}\text { Sifat papan blok } \\
\text { (Block board properties) }\end{array}$} & \multirow{2}{*}{$\begin{array}{l}\text { Tebal bilah inti } \\
\text { (Thickness of } \\
\text { strip), B }\end{array}$} & \multicolumn{3}{|c|}{$\begin{array}{l}\text { Lebar bilah inti } \\
\text { (Width of strip), } \mathrm{A}\end{array}$} \\
\hline & & & $\overrightarrow{\mathrm{a} 1}$ & $\mathrm{a} 2$ & a3 \\
\hline \multirow[t]{2}{*}{1.} & Kadar air (Moisture content), $\%$ & b1 & 12,06 & 11,97 & 11,95 \\
\hline & & b2 & 11,77 & 11,96 & 12,05 \\
\hline \multirow[t]{2}{*}{2.} & Kerapatan (Density), $\mathrm{g} / \mathrm{cm}^{3}$ & b1 & 0,41 & 0,42 & 0,43 \\
\hline & & b2 & 0,41 & 0,43 & 0,44 \\
\hline \multirow[t]{7}{*}{3.} & $\begin{array}{l}\text { Pengembangan dimensi setelah } \\
\text { direndam air dingin selama } 24 \text { jam } \\
\text { (Dimension expansion after } 24 \text { hours } \\
\text { immersion), } \%\end{array}$ & & & & \\
\hline & - Tebal (Thickness) & b1 & 5,02 & 5,98 & 4,53 \\
\hline & & b2 & 5,39 & 6,07 & 4,74 \\
\hline & - Panjang (Length) & b1 & 0,37 & 0,53 & 0,29 \\
\hline & & b2 & 0,56 & 0,62 & 0,55 \\
\hline & - Lebar (Width) & b1 & 0,37 & 0,68 & 0,54 \\
\hline & & b2 & 0,61 & 0,75 & 0,57 \\
\hline
\end{tabular}

Keterangan (Remarks) : A = Lebar bilah inti (Width of strip); $11=0,70 \mathrm{~cm} ; \mathrm{a} 2=2,5 \mathrm{~cm} ; \mathrm{a} 3=7,6$ $\mathrm{cm} ; \mathrm{B}=$ Tebal bilah inti (Thickness of strip); $\mathrm{b} 1=1 \mathrm{~cm} ; \mathrm{b} 2=1,5 \mathrm{~cm} ; / /=$ Sejajar serat (Parallel to grain); $\perp=$ Tegak lurus serat (Perpendicular to grain).

Pengembangan dimensi papan blok sengon adalah 5,11\% (2,44 - 7,66\%) untuk pengembangan tebal, $0,50 \%(0,25-0,71 \%)$ untuk pengembangan panjang dan $0,61 \%(0,35$ $0,80 \%$ ) untuk pengembangan lebar (Sulastiningsih et al., 1995). Data ini hampir sama dengan data yang dikemukakan di atas, yang berarti pemakaian venir silang tusam tidak menyebabkan perbedaan sifat pengembangan dimensi papan blok yang besar.

Pengembangan tebal papan blok dipengaruhi oleh lebar bilah inti, sedangkan tebal bilah inti tidak mempengaruhinya (Tabel 2). Hal ini sejalan dengan hasil penelitian papan blok yang terbuat dari kayu sengon semua (Sulastiningsih et al., 1995). Berdasarkan hasil uji beda pada Lampiran 1 ternyata bahwa pengembangan tebal yang terbesar terjadi pada papan blok dengan lebar bilah inti 2,5 cm (a2), sedangkan yang terkecil pada papan blok dengan lebar bilah inti 7,6 cm (a3) dan untuk bilah inti $0,70 \mathrm{~cm}$ (a1) berada di antara keduanya. Hal serupa dikemukakan pula oleh Sulastiningsih et al. (1995) yang meneliti papan blok dari kayu sengon semua.

Lebar bilah inti, tebal bilah inti dan interaksinya tidak mempengaruhi pengembangan panjang papan blok (Tabel 2), sedangkan menurut Sulastiningsih et al. (1995) ketiga faktor tesebut mempengaruhinya. Hal ini mungkin disebabkan oleh perbedaan jenis kayu dari venir silang yaitu pada penelitian ini menggunakan jenis kayu tusam sedangkan pada penelitian 
Sulastiningsih et al. (1995) menggunakan venir silang sengon. Penyusutan pada arah tangensial dalam kayu tusam (8,3\%) lebih besar dari pada penyusutan kayu sengon $(5,2 \%)$ (Martawijaya,1989). Penyusutan venir silang kearah lebar, sama dengan penyusutan kearah tangensial, karena venir silang arahnya tegak lurus bilah inti maka dapat menahan pengembangan bilah inti kearah panjang. Penyusutan venir silang tusam yang lebih besar dari pada venir silang sengon berarti akan lebih banyak menahan pengembangan bilah inti ke arah panjang.

Pengembangan lebar papan blok dipengaruhi oleh lebar bilah inti, tebal bilah inti dan interaksinya (Tabel 2), sedangkan menurut Sulastiningsih et al. (1995) hanya dipengaruhi oleh tebal bilah inti saja. Berdasarkan hasil uji beda pada Lampiran 1, ternyata bahwa pengembangan lebar yang terbesar terdapat pada lebar bilah inti 2,5 (a2), sedangkan yang terkecil pada lebar bilah inti $0,70 \mathrm{~cm}$ (a1) dan untuk lebar bilah inti $7,6 \mathrm{~cm}$ (a3) berada diantaranya. Sementara itu pengembangan lebar papan blok dengan tebal bilah inti $1,5 \mathrm{~cm}$ (b2) lebih besar dari pada tebal bilah inti $1 \mathrm{~cm}$ (b1). Walaupun demikian karena interaksinya nyata patut diperhatikan pengaruh bersama lebar dan tebal bilah inti (AB).

Berdasarkan hasil uji beda pada Lampiran 1 ternyata pengembangan lebar yang terbesar terdapat pada papan blok dengan lebar bilah inti $2,5 \mathrm{~cm}$ dan tebal bilah inti $1,5 \mathrm{~cm}(\mathrm{a} 2 \mathrm{~b} 2)$, pengembangan lebar yang terkecil terdapat pada papan blok dengan lebar bilah inti $0,70 \mathrm{~cm}$ dan tebal bilah inti $1 \mathrm{~cm}$ (a1b1), sedangkan kombinasi lainnya tidak memberikan perbedaan yang nyata.

Keteguhan rekat papan blok berkisar antara 7,45 hingga 9,8 kg/ $\mathrm{cm}^{2}$ dengan rata-rata $8,33 \mathrm{~kg} / \mathrm{cm}^{2}$. Jika dibandingkan dengan Standar Indonesia maka keteguhan rekat papan blok yang dibuat dengan berbagai perlakuan memenuhi syarat standar tersebut karena nilainya tidak kuang dari $7 \mathrm{~kg} / \mathrm{cm}^{2}$. Hasil sidik ragam pada Tabel 3 menunjukkan bahwa keteguhan rekat papan blok dipengaruhi oleh lebar bilah inti, sedangkan tebal bilah inti dan interaksi antara lebar dan tebal bilah inti tidak menunjukkan pengaruh yang nyata. Hasil uji beda pada Lampiran 1 menunjukkan bahwa lebar bilah inti $0,7 \mathrm{~cm}$ tidak berbeda nyata dengan lebar bilah inti $7,6 \mathrm{~cm}$. Nilai keteguhan rekat tertinggi $\left(9,45 \mathrm{~kg} / \mathrm{cm}^{2}\right)$ terdapat pada papan blok dengan lebar bilah $2,5 \mathrm{~cm}$.

Untuk menilai kualitas perekatan papan blok dapat dilakukan dengan uji delaminasi. Hasil pengujian menunjukkan bahwa tidak terjadi delaminasi pada semua papan blok yang dibuat dengan berbagai perlakuan (Tabel 2). Dengan demikian papan blok tersebut semuanya memenuhi syarat Standar Indonesia karena panjang delaminasinya kurang dari 2,5 cm.

Keteguhan lentur papan blok sengon dengan venir silang kayu tusam dinyatakan dalam modulus patah pada arah sejajar dan tegak lurus serat (Tabel 2). Nilai keteguhan lentur papan blok pada arah sejajar serat berkisar antara $213,09 \mathrm{~kg} / \mathrm{cm} 2$ hingga $271,43 \mathrm{~kg} / \mathrm{cm}^{2}$ dengan ratarata $253,27 \mathrm{~kg} / \mathrm{cm}^{2}$, pada arah tegak lurus serat berkisar antara $167,89 \mathrm{~kg} / \mathrm{cm}^{2}$ hingga 224,72 $\mathrm{kg} / \mathrm{cm}^{2}$ dengan rata-rata $201,14 \mathrm{~kg} / \mathrm{cm}^{2}$. Keteguahan lentur papan blok pada arah sejajar serat lebih tinggi dari pada tegak lurus serat. Hal ini disebabkan yang sejajar serat berarti sejajar bilah inti karena papan blok yang dibuat 5 lapis. Sebagaimana diketahui bahwa keteguhan lentur kayu utuh pada arah sejajar serat jauh lebih besar dari pada tegak lurus serat. 
Tabel 2. Nilai rata-rata sifat mekanis papan blok Tabel 2. Mean values of mechanical properties of block board

\begin{tabular}{|c|c|c|c|c|c|}
\hline \multirow[t]{2}{*}{ No } & \multirow{2}{*}{$\begin{array}{l}\text { Sifat papan blok } \\
\text { (Block board properties) }\end{array}$} & \multirow{2}{*}{$\begin{array}{c}\text { Tebal bilah inti } \\
\text { (Thickness of } \\
\text { strip), B }\end{array}$} & \multicolumn{3}{|c|}{$\begin{array}{l}\text { Lebar bilah inti } \\
\text { (Width of strip), } \mathrm{A}\end{array}$} \\
\hline & & & a1 & $\mathrm{a} 2$ & a3 \\
\hline \multirow[t]{3}{*}{1} & Keteguhan rekat (Bonding strength) & & & & \\
\hline & - Beban putus (Failing load), $\mathrm{kg} / \mathrm{cm}^{2}$ & b1 & 7,45 & 9,1 & 7,8 \\
\hline & & b2 & 8,07 & 9,8 & 7,74 \\
\hline \multirow[t]{2}{*}{. } & - Kerusakan kayu (Wood failure), \% & b1 & 62,5 & 52,5 & 50,8 \\
\hline & & b2 & 66,5 & 71,1 & 58,3 \\
\hline \multirow[t]{2}{*}{2} & Delaminasi (Delamination), $\mathrm{cm}$ & b1 & 0 & 0 & 0 \\
\hline & & b2 & 0 & 0 & 0 \\
\hline \multirow[t]{5}{*}{3} & $\begin{array}{l}\text { Modulus patah (Modulus of rupture), } \\
\mathrm{kg} / \mathrm{cm}^{2}\end{array}$ & & & & \\
\hline & // & b1 & 213,09 & 257,67 & 263,73 \\
\hline & & b2 & 252,27 & 261,44 & 271,43 \\
\hline & $\perp$ & b1 & 206,25 & 196,15 & 167,89 \\
\hline & & b2 & 224,72 & 219,15 & 192,41 \\
\hline
\end{tabular}

Keterangan (Remarks): A= Lebar bilah inti (Width of strip); $1=0,70 \mathrm{~cm} ; \mathrm{a} 2=2,5 \mathrm{~cm} ; \mathrm{a} 3=$ $7,6 \mathrm{~cm} ; \mathrm{B}=$ Tebal bilah inti (Thickness of strip); $\mathrm{b} 1=1 \mathrm{~cm} ; \mathrm{b} 2=1,5 \mathrm{~cm} ; / /=$ Sejajar serat (Parallel to grain); $\perp=$ Tegak lurus serat (Perpendicular to grain).

Keteguhan lentur tegak lurus serat papan blok dipengaruhi oleh lebar bilah inti dan tebal bilah inti, sedangkan interaksinya tidak mempengaruhinya. Berdasarkan data pada Tabel 2 dapat diketahui bahwa semakin tebal bilah inti semakin tinggi keteguhan lentur tegak lurus serat papan blok dan sebaliknya semakin lebar bilah inti semakin kecil keteguhan lentur tegak lurus serat papan blok. 
Tabel 3. Ringkasan sidik ragam sifat papan blok Tabel 3. Summarized analysis of variance of block board properties

\begin{tabular}{|c|c|c|c|c|c|c|c|}
\hline \multirow{3}{*}{$\begin{array}{c}\text { Sumber } \\
\text { keragaman } \\
\text { (Source of variance) }\end{array}$} & \multirow{3}{*}{$\begin{array}{l}\text { Derajat } \\
\text { Bebas } \\
\text { (Degree of } \\
\text { freedom })\end{array}$} & \multicolumn{6}{|c|}{ F hitung ( $F$ calculated $)$} \\
\hline & & \multicolumn{3}{|c|}{ Pengembangan (Expansion) } & \multicolumn{2}{|c|}{$\begin{array}{c}\text { Keteguhan } \\
\text { lentur } \\
\text { (Bending strength) }\end{array}$} & \multirow{2}{*}{$\begin{array}{l}\text { Keteguhan } \\
\text { rekat } \\
\text { (Bonding } \\
\text { stength) }\end{array}$} \\
\hline & & $\begin{array}{c}\text { Tebal } \\
\text { (Thickness) }\end{array}$ & $\begin{array}{l}\text { Panjang } \\
\text { (Length) }\end{array}$ & $\begin{array}{c}\text { Lebar } \\
\text { (Width) }\end{array}$ & // & $\perp$ & \\
\hline $\begin{array}{l}\text { Lebar bilah inti } \\
\text { (Width of strip), } \\
\text { A }\end{array}$ & 2 & $18,43^{* *}$ & 0,94 & $297,27 * *$ & 1,69 & $72,09 * *$ & $5,11 *$ \\
\hline $\begin{array}{l}\text { Tebal bilah inti } \\
\text { (Thicknes of } \\
\text { strip), B }\end{array}$ & 1 & 1,42 & 1,79 & $206,59 * *$ & 0,23 & $20,16 * *$ & 0,90 \\
\hline$A \times B$ & 2 & 0,18 & 1,02 & $68,65^{* *}$ & 1,43 & 3,29 & 0,83 \\
\hline
\end{tabular}

Keterangan (Remarks): * = Nyata (Significant); ** = Sangat nyata (Highly significant)

Hasil penelitian Sulastiningsih et al. (1995) menunjukkan bahwa keteguhan lentur ratarata papan blok yang terbuat dari kayu sengon adalah $238,49 \mathrm{~kg} / \mathrm{cm}^{2}$ pada arah sejajar serat dan $172,45 \mathrm{~kg} / \mathrm{cm}^{2}$ pada arah tegak lurus serat. Data ini lebih rendah dari pada keteguhan lentur papan blok sengon dengan venir silang tusam seperti dikemukakan diatas. Hal ini dapat dipahami karena tusam termasuk kelas kuat III sedangkan sengon termasuk kelas kuat IV- V (Oey Djoen Seng, 1964).

Keteguhan lentur rata-rata papan blok yang dibuat dengan venir silang kayu tusam adalah $253,27 \mathrm{~kg} / \mathrm{cm}^{2}$ pada arah sejajar serat dan $204,60 \mathrm{~kg} / \mathrm{cm}^{2}$ pada arah tegak lurus serat. Dengan demikian penggunaan venir silang kayu tusam dalam pembuatan papan blok sengon dapat meningkatkan keteguhan lentur sebesar 6,2\% pada arah sejajar serat dan 18,6\% pada arah tegak lurus serat. Keteguhan lentur sejajar serat papan blok sengon yang dibuat dengan venir silang kayu tusam semuanya memenuhi Standar Jerman karena nilainya tidak kurang dari $200 \mathrm{~kg} / \mathrm{cm}^{2}$.

\section{KESIMPULAN}

1. Kadar air papan blok ada diantara 11,77 hingga $12,06 \%$ dengan rata-rata $12 \%$. Kerapatan papan blok ada diantara $0,41 \mathrm{~g} / \mathrm{cm}^{3}$ hingga $0,44 \mathrm{~g} / \mathrm{cm}^{3}$ dengan rata-rata $0,42 \mathrm{~g} / \mathrm{cm}^{3}$.

2. Ukuran lebar bilah inti mempengaruhi pengembangan tebal dan pengembangan lebar tetapi tidak mempengaruhi pengembangan panjang papan blok. Tebal bilah inti mempengaruhi pengembangan lebar papan blok tetapi tidak mempengaruhi pengembangan tebal dan pengembangan panjang papan blok. 
JURNAL Penelitian Hasil Hutan Vol. 24 No. 2, April 2006: 145-155

3. Keteguhan rekat papan blok berdasarkan uji geser tarik dan uji delaminasi memenuhi syarat standar Indonesia untuk semua perlakuan. Keteguhan rekat papan blok dengan uji geser tarik dipengaruhi oleh lebar bilah inti, sedangkan tebal bilah inti tidak berpengaruh.

4. Penggunaan venir silang kayu tusam dalam pembuatan papan blok sengon dapat meningkatkan keteguhan lentur sebesar 6,2\% pada arah sejajar serat dan 18,6\% pada arah tegak lurus serat.

5. Keteguhan lentur sejajar serat papan blok sengon yang dibuat dengan venir silang kayu tusam semuanya memenuhi Standar Jerman karena nilainya tidak kurang dari 200 $\mathrm{kg} / \mathrm{cm}^{2}$.

\section{DAFTAR PUSTAKA}

Anonim. 1966. Plywood and Other Wood-Based Panels Food and Agriculture Organization. Rome.

. 11975. DIN Taschenbuch 60, Beuth Verlag Gmbh. Berlin.

. 1995a. Buku Kerja 1995. Perum Perhutani. Jakarta.

1995b. Standard Test Methods for Evaluating Properties of Wood-Base Fiber and Particle Panel Materials. Annual Book of ASTM Standards. ASTMD 1037-93.

2002. Papan blok penggunaan umum. Badan Standarisasi Nasional. Jakarta. SNI 01-5008.12-2002.

. 2002. Kayu lapis penggunaan umum. Badan Standarisasi Nasional. Jakarta. SNI 015008.2-2000.

2004. Laporan Hasil Monitoring Kayu Bulat Asal Hutan Tanaman. Dinas Kehutanan Propinsi Jawa Barat. Bandung.

Hidayat, N., B. Tambunan dan P. Sutigno, 1978. Papan Blok dengan Berbagai Jenis dan Tebal Venir. Kehutanan Indonesia 5 (1) : 28-32. Jakarta.

Martawijaya, A., I. Kartasujana, Y.I. Mandang, S.A. Prawira, K.Kadir. 1989. Atlas Kayu Indonesia Jilid II. Badan Penelitian dan Pengembangan Kehutanan. Bogor.

Oey Djoen Seng. 1964. Berat Jenis dari Jenis-jenis Kayu Indonesia dan Pengertian Beratnya Kayu untuk Keperluan Praktek. Pengumuman LPHH No. 1. Bogor.

Prajadinata, S. dan Masono. 1989. Teknik Penanaman Sengon (Albizia falcataria L. Fosberg). Informasi Teknis No. 6. Pusat Penelitian dan Pengembangan Hutan. Bogor.

Sulastiningsih, I.M., P. Sutigno dan M.I. Iskandar. 1995. Pengaruh Ukuran Bilah Kayu Sengon Terhadap Beberapa Sifat Papan Blok. Jurnal Penelitian Hasil Hutan 13 (5) : 186 - 195. Pusat Penelitian dan Pengembangan Hasil Hutan dan Sosial Ekonomi Kehutanan. Bogor.

Sutigno, P. 1991. Kayu Majemuk Perkembangan dan Masa Depannya di Indonesia. Orasi Pengukuhan Ahli Peneliti Utama. Badan Penelitian dan Pengembangan Kehutanan. Jakarta. 
Lampiran 1. Uji beda beberapa sifat papan blok Appendix 1. Test of significant difference of some block board properties

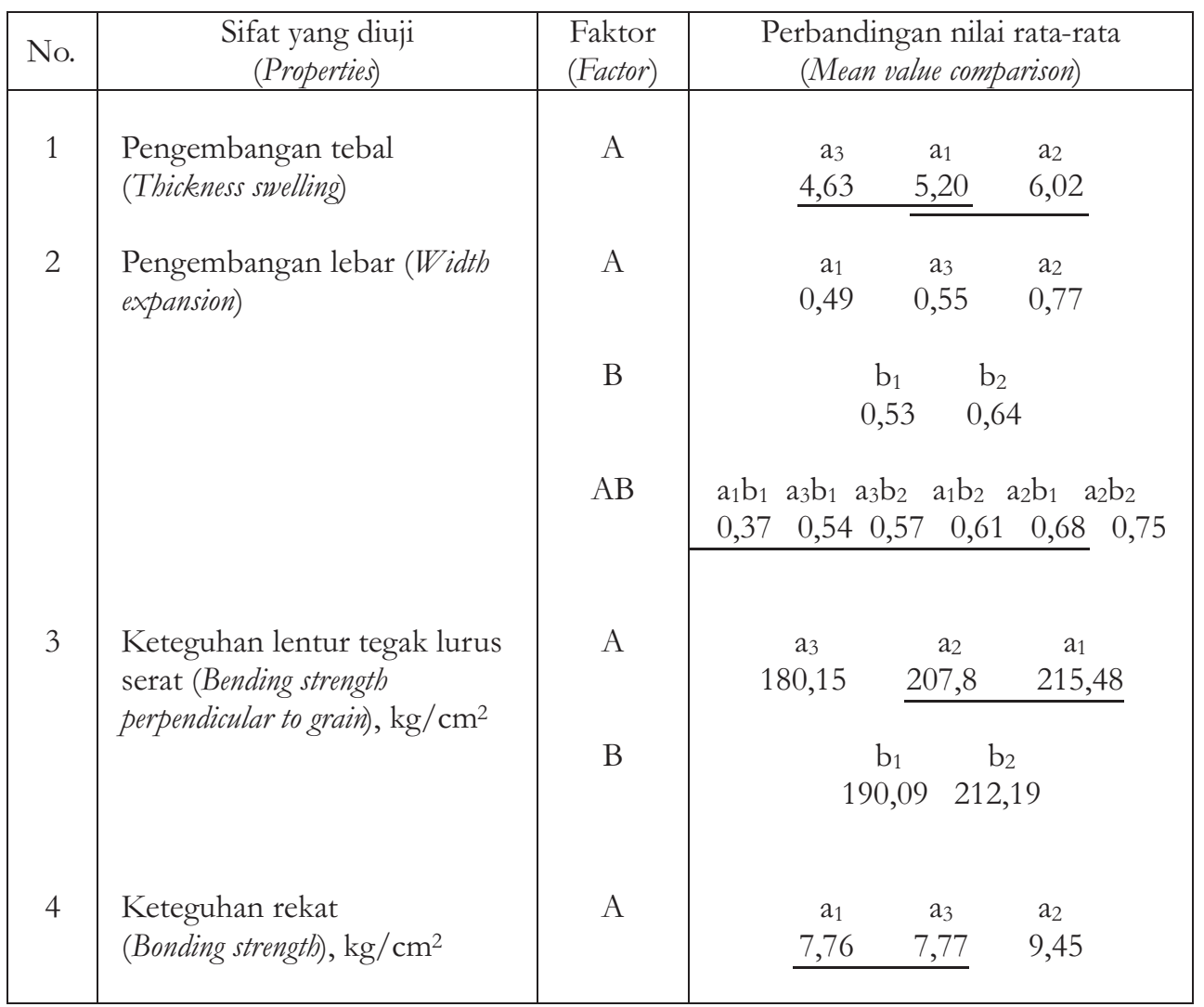

